Research Article

\title{
Value Preferences and Intergenerational Differences of Tourists to Traditional Chinese Villages
}

\author{
Wei Qi, ${ }^{1}$ Lin Li $\mathbb{D}^{2}{ }^{2}$ and Jie Zhong ${ }^{3}$ \\ ${ }^{1}$ School of Tourism Management, Anhui Technical College of Industry and Economy, Hefei 230051, China \\ ${ }^{2}$ College of Tourism, Beijing Union University, Beijing 100101, China \\ ${ }^{3}$ College of Architecture and Urban Planning, Anhui Jianzhu University, Hefei 230022, China
}

Correspondence should be addressed to Lin Li; lilin@buu.edu.cn

Received 3 June 2021; Revised 15 July 2021; Accepted 30 July 2021; Published 10 August 2021

Academic Editor: Guangdong Wu

Copyright (C) 2021 Wei Qi et al. This is an open access article distributed under the Creative Commons Attribution License, which permits unrestricted use, distribution, and reproduction in any medium, provided the original work is properly cited.

\begin{abstract}
Tourist values determine the behavior of tourists. To pinpoint the behaviors and preferences of tourists, it is necessary to explore their value orientation and intergenerational differences. The exploration is of great significance to the activation of tourism in traditional villages. After analyzing the value of tourists to two traditional villages (Hongcun and Xidi), this paper investigated the value preferences and intergenerational differences of tourists of four generations to traditional villages, using means-end chain (MEC) theory and hard laddering. Through a questionnaire survey on tourists born in the 1960s, 1970s, 1980s, and 1990s, the authors established 36 MEC value chains of 18 classes. The results show that the post-60s traditional village tourists are a generation of wisdom-loving learners, who prefer the values of wisdom and self-improvement; the post-70s and 80s tourists are a generation of beauty lovers with a strong sense of belonging, who prefer the values of beautiful world, inner harmony, and sense of belonging; the post-90s tourists are a generation of inclusive advocators of diversity, with no special value preference. These results provide theoretical support and practical enlightenment for the market segmentation of traditional village tourism and the protection and activation of traditional villages.
\end{abstract}

\section{Introduction}

Traditional villages are the basic units of rural China and the living fossils of traditional culture [1]. In June 2019, the Chinese Ministry of Housing and Urban-Rural Development, in association with other departments, released the fifth batch of Chinese traditional villages. In total, 6,819 traditional villages are being protected in China. The main protective method is to activate tourism to these villages [2]. The ancient village tourism and rural tourism are an important means to activate and protect traditional villages [3]. Driven by the boom of domestic tourism, the purpose of traditional village tourism has shifted from sightseeing to both sightseeing and vacation. Thanks to unique regional cultures, improving infrastructure, better public services, and new business products, traditional villages are attracting more and more tourists of different generations.
At present, fruitful results have been achieved on the description of the behavior features of tourists to traditional villages. However, there is a lack of in-depth research on the intergenerational differences of tourists. The Travel Industry Association of America (TIA) considered intergenerational analysis as the most common and effective approach for dividing the population and segmenting the market. Tourists of different generations vary significantly in behavior features and preferences [4]. A good understanding of the intergenerational differences in tourist behaviors helps to mine the deep-seated inducers of their tourism behaviors and preferences [5]. On this basis, it is possible to accurately predict the value preferences of tourists of different generations [6] and segment the market to provide products and services tailored to their needs, thereby promoting the sustainable development of traditional village tourism. The tourists' pursuit of value is the fundamental determinant of their travel behaviors [7]. Therefore, this paper analyzes the values of tourists of 
different generations to traditional villages through hard laddering, a technique of means-end chain (MEC), and tries to disclose the value preferences and intergenerational differences between traditional village tourists.

\section{Literature Review}

2.1. Traditional Village Tourism. The development of traditional villages as travel destinations is always accompanied by the game between core stakeholders, dormant stakeholders, and marginal stakeholders. There are differences and interconnections between these stakeholders [8]. Culture and environment are their common focuses [9]. The government plays a decisive role in the development of traditional village tourism [10], which suffers the greatest impact from community and residents [11]. Being the owners of traditional villages, the residents determine how well the tourism of these villages develops with their satisfaction, support, and active participation [12-17]. Therefore, the active involvement of the community can promote the sustainable development of tourism in traditional villages $[18,19]$, enhance community capacity [20], spur community development $[21,22]$, and underpin the good interaction between community and tourism. Hence, the development of traditional village tourism is not only a game, but also the symbiosis of multiple stakeholders.

Symmetrical reciprocity and integrated symbiosis are the optimization objectives of the symbiosis systems for traditional villages [23, 24], such as the "community participation + enterprise operation" model of stakeholders [25], the typical model of valley economy in mountainous regions [26], the diversified mixed effect model of market game [27], and the synchronized/asynchronized "urbanization + community participation + protection zone" model [28].

During the game and symbiosis of stakeholders in the development of traditional village tourism, the space of traditional villages is evolving into two social spaces, namely, tourist area and resident area, with the continued growth of tourist immigrants and tourists. Some traditional villages have developed into small towns [10], creating new ethnic cultures [29]. In this process, the spatial social order has also been reorganized: the niche space of community populations is replaced by tourist populations, which occupy the core area of traditional villages [30]. Driven by tourism interests, the tertiary industry-centered land urbanization has taken place around some traditional villages. The population is dominated by residents and tourism practitioners. Under the influence of outside cultures, the original residents of traditional villages are increasingly urbanized and modernized [31], and the rural culture is shifting from traditional farming culture to modern culture [32].

In the development of traditional village tourism, culture is the soul and resources are the body [33]. The tourism resources of traditional villages include the local environment, village shape, human landscape, and local culture [34-37], which embody the history, culture, and artistic value of traditional villages [38]. This precious heritage wins the favor of tourists. With the emerging demand from niche markets of tourism, new businesses spring up in the tourism industry.
For example, the sketching tourism, research tourism, sports tourism, and gourmet tourism in traditional villages are very popular among tourists $[39,40]$. Being the subjects of traditional village tourism, tourists attach the greatest importance to the authenticity of architecture and cultural relics $[41,42]$, and their primary travel motives are experiencing traditional culture, sightseeing, and family trips [43-46]. The existing studies on the niche markets of tourism in traditional villages mostly discuss the consumption behaviors of overseas tourists, female tourists, and sketching tourists [47-49], as well as the trend and seasonal variation of tourism demand [50]. However, there is not yet any discovery about the niche markets, value preferences, or intergenerational differences of traditional village tourists of different generations.

2.2. Theory of Generations. Based on anthropology, Mannheim [51] proposed the theory of generations, which holds that people born in the same period have the same position in the historical process of social development and form common values, thinking patterns, and behavioral features, as they experience the same major external events. The theory of generations is composed of three progressive concepts: the site of generation, the realistic sense of generation, and the intrageneration division. This theory has been further verified, extended, and improved by many scholars [52-54], who found that different generations differ markedly; the intrageneration values are relatively stable and directly affect future behaviors and attitudes [55]; intragenerational personalities and features are predictable [6].

Foreign researchers have relied on the theory of generations for empirical analysis of tourist preferences for consumption behaviors and intergenerational differences. Most of them tackled the behaviors and preferences of tourists in two or three generations $[6,56-63]$. In recent years, researchers from countries and regions like South Korea, the United States, and Taiwan have explored the intergenerational differences in the travel behaviors of strait tourists from Chinese mainland [4]. Nevertheless, the research results are not necessarily valid, because the researchers adopted the division rules for foreign generations and did not know much about the situation in Chinese mainland. In China, the studies on the generational behaviors of domestic tourism consumers mainly deal with the behavior differences between tourists born in the 1980s and 1990s [64, 65]; the differences in the impression of destinations between the tourism consumers born in the 1950s, 1960s, and 1970s [66]; and the description of the behavior differences between tourism consumers across generations $[5,67]$, female tourism consumers [68], domestic tourism consumers in scenic spots [69], and tourists searching for tourism information [70]. However, the sample sizes are relatively small, without many samples on the national scale.

\section{Research Design}

This paper designs a questionnaire survey based on hard laddering. All the questions were extracted from the literature and in-depth interviews (Table 1). In 2019, the authors 
TABLE 1: The As, Cs, and Vs of traditional village tourists born in the 1960s, 1970s, 1980s, and 1990s.

\begin{tabular}{lcc}
\hline Attributes (As) & Consequences (Cs) & Values (Vs) \\
\hline A1, ancient architecture & C1, culinary experience & V1, inner harmony \\
A2, water system of traditional village & C2, harmony between man and nature & V2, satisfaction \\
A3, local delicacies & C3, gaining experience & V3, self-improvement \\
A4, environment of traditional village & C4, ecological protection & V4, sense of belonging \\
A5, local traditional culture & C5, spirit of workmanship & V5, wisdom \\
A6, engravings/couplets & C6, wisdom of the ancients & V6, sense of security \\
A7, lifestyle of residents & C7, cultural experience and inheritance & V7, beautiful world \\
A8, family tours & C8, picturesque landscape & V8, long-lasting life \\
A9, native products & C9, escaping from reality & V9, cleanness \\
A10, layout of traditional village & C10, idyllic life & V10, joy \\
A11, natural landscape around traditional village & C11, neatness & - \\
- & C12, beauty & - \\
- & C13, shopping experience & - \\
- & C14, novel experience & - \\
- & C15, lodging experience & - \\
\hline
\end{tabular}

The categories of "attribute, consequence, and value" are determined based on the first-hand data obtained from the soft-step progressive interview.

conducted a stratified sampling [71] on weijuan.com. Taking generation, gender, and residence as control variables, the questionnaire survey targets $60 \mathrm{~s}, 70 \mathrm{~s}, 80 \mathrm{~s}$, and 90 s tourists who had traveled to traditional villages in the previous 12 months. The occupation and education of the respondents were also taken into account. A total of 642 questionnaires were recovered, including 600 valid ones (Table 2).

The data analysis was carried out in four steps, as suggested by Reynolds and Olson [72], Gong [73], Kim et al. [74], and Richter and Bokelmann [75] for hard laddering. The correlation between attribute (A) and consequence (C) was obtained through questionnaire survey. The questionnaire is divided into three layers to design questions. First, visitors are asked to choose the attribute motivation of rural tourism, then to choose the possible results caused by the attribute motivation, and finally to choose the value motivation caused by the results. In the questionnaire, there is a blank item after each $\mathrm{C}_{i}$ item, and the respondents are asked to fill in the result caused by $\mathrm{A}_{i}$ (multiple choices can be made), so as to establish a connection. Firstly, the frequency of each attribute (A) motive, consequence $(\mathrm{C})$ motive, and value $(\mathrm{V})$ motive was counted, so it was with the number of consequence-value connections. Secondly, the As, Cs, and Vs were tabulated, and the frequency of $\mathrm{A}-\mathrm{C}$ and $\mathrm{C}-\mathrm{V}$ connections was quantified. We counted the occurrence times of $\mathrm{A}_{i}, \mathrm{C}_{i}$, and $\mathrm{V}_{i}$ in the questionnaire, respectively, to calculate the frequency. According to the results of the questionnaire, the frequency of the occurrence of $\mathrm{A}_{i}$ was marked as $N_{\mathrm{A} i}$, and then the number of the results $\mathrm{C}_{j}$ brought by $\mathrm{A}_{i}$ (the data obtained from the questionnaire) was counted and marked as $n_{\mathrm{C} j}$, so the quantitative relationship between $\mathrm{A}_{i}$ and $\mathrm{C}_{j}$ could be expressed as $n_{\mathrm{c} j} / N_{\mathrm{A} i}$. The quantitative relationship between $\mathrm{C}$ and $\mathrm{V}$ was similar to this. Thirdly, the cut-off point for analysis was determined based on the quantified data of A-C and $\mathrm{C}-\mathrm{V}$ connections. Finally, the data above the cut-off point was plotted into a hierarchical value map (HVM) of MEC value chains. Each row of the HVM was analyzed, revealing the value preferences and intergenerational differences of traditional village tourists.

\section{Results}

According to the survey data, two interconnected matrices were set up for the A-C connections (Table 3 ) and $\mathrm{C}-\mathrm{V}$ connections (Table 4) selected by these respondents, and the cut-off point of the analysis was set to 50\% (any data greater than or equal to $49.5 \%$ were treated as equal to $50 \%$ ). The data above the cut-off point of $50 \%$ were selected to build the HVM, forming MEC value chains (A-C-V). In the HVM, the connections between $\mathrm{A}, \mathrm{C}$, and $\mathrm{V}$ are shown in percentages, reflecting the proportion of tourists to each connection [75]. The percentages help to determine the important Cs and Vs [76]. According to the criteria of the $50 \%$ cutoff point, 75 or more of the 150 questionnaires selected attribute motivation to be marked, respectively, as follows: A4, traditional village environment atmosphere $(n=101 / 67.3 \%)$; A5, local traditional culture ( $n=96 / 64.0 \%, 64.0 \%)$; A3, local characteristic food $(n=95 / 63.3 \%, 63.3 \%)$ motivation; A1, attribute motivation of ancient building and $\mathrm{B} \& \mathrm{~B}(n=88 / 58.7 \%, 58.7 \%)$; A10, pattern of traditional villages $(n=76 / 50.7 \%, 50.7 \%)$.

\subsection{MEC Value Chains of the Post-60s Traditional Village} Tourists. A total of 150 post-60s tourists were surveyed. According to the survey data, two interconnected matrices were set up for the A-C connections (Table 3) and $\mathrm{C}-\mathrm{V}$ connections (Table 4) selected by these respondents. The number of A-C connections (Table 5) and $\mathrm{C}-\mathrm{V}$ connections (Table 6) being selected by the respondents was counted and used to prepare the HVM for the MEC value chains (A-C-V) of the post-60s tourists (Figure 1).

Based on $50 \%$ of the cut-off point to build hierarchical value map (HVM), six MEC value chains have been formed, including three attributes such as ancient building, local traditional culture, and local characteristics food; four consequences such as the wisdom of the ancients, spirit, culture and heritage, and dining experience; and four values such as wisdom, self-improvement, satisfaction, and happiness. 
TABLe 2: Demographic statistics of respondents in traditional villages $(n=600)$.

\begin{tabular}{|c|c|c|}
\hline & Population information & Percentage \\
\hline \multirow{2}{*}{ Gender } & Male & 52.0 \\
\hline & Female & 48.0 \\
\hline \multirow{4}{*}{ Generation } & Post-60s & 25.0 \\
\hline & Post-70s & 25.0 \\
\hline & Post-80s & 25.0 \\
\hline & Post-90s & 25.0 \\
\hline \multirow{4}{*}{ Education } & Junior high school & 2.0 \\
\hline & Senior high school or secondary technical/vocational school & 19.0 \\
\hline & Undergraduate college/junior college & 75.0 \\
\hline & Graduate school and above & 4.0 \\
\hline \multirow{8}{*}{ Occupation } & Civil servant & 5.8 \\
\hline & Manager of enterprise/public institution & 27.0 \\
\hline & Staff member/worker & 40.2 \\
\hline & Self-employed & 11.2 \\
\hline & Education/research/cultural practitioner & 9.3 \\
\hline & Freelancer & 4.0 \\
\hline & Student & 1.5 \\
\hline & Others & 1.0 \\
\hline
\end{tabular}

TABLE 3: C motives of the post-60s traditional village tourists.

\begin{tabular}{|c|c|c|c|c|c|c|c|c|c|c|c|c|}
\hline A-C & $\mathrm{A} 1$ & A2 & A3 & A4 & A5 & A6 & A7 & A8 & A9 & A10 & A11 & $n$ \\
\hline $\mathrm{C} 1$ & - & - & 65 & - & - & - & - & 2 & 18 & - & - & 85 \\
\hline $\mathrm{C} 2$ & 19 & 15 & - & 15 & 16 & 3 & - & 3 & - & 24 & 23 & 118 \\
\hline C3 & 34 & 25 & 37 & 23 & 39 & 23 & 17 & 10 & 9 & 24 & 10 & 251 \\
\hline C4 & 15 & 31 & 10 & 40 & 19 & 11 & 15 & 3 & 7 & 26 & 28 & 205 \\
\hline C5 & 54 & 18 & - & 21 & 18 & 25 & 9 & 3 & 2 & 17 & 6 & 173 \\
\hline C6 & 55 & 22 & 15 & 24 & 35 & 18 & 12 & 2 & 1 & 21 & 7 & 212 \\
\hline C7 & 30 & 17 & 28 & 34 & 48 & 19 & 31 & 5 & 8 & 31 & 12 & 263 \\
\hline C8 & 22 & 32 & - & 36 & 20 & - & - & 5 & - & 18 & 33 & 166 \\
\hline C9 & 11 & 11 & - & - & 17 & 13 & 11 & 3 & - & - & 7 & 73 \\
\hline $\mathrm{C} 10$ & 18 & 19 & 31 & 41 & 25 & 13 & 36 & 3 & 6 & 25 & 25 & 242 \\
\hline $\mathrm{C} 11$ & 16 & 13 & 23 & 30 & 17 & 13 & 18 & 3 & 5 & 9 & 13 & 160 \\
\hline C12 & 8 & 17 & 11 & 19 & 10 & 7 & 9 & 2 & 3 & 9 & 22 & 117 \\
\hline $\mathrm{C} 13$ & - & - & 12 & 12 & - & - & 8 & 3 & 22 & - & - & 114 \\
\hline C14 & 14 & 10 & 17 & 19 & 24 & 8 & 17 & 2 & 12 & 17 & 13 & 153 \\
\hline C15 & 8 & 5 & - & 10 & 10 & 3 & 16 & 1 & 3 & 13 & - & 138 \\
\hline $\mathrm{C} 16$ & 9 & 4 & 17 & 14 & 10 & 4 & 6 & 1 & 8 & 9 & 18 & 100 \\
\hline
\end{tabular}

$n$ is the number of connections. $C_{i j}$ is the amount of $C_{j}$ caused by $A_{i}$.

TABLE 4: V motives of the post-60s traditional village tourists.

\begin{tabular}{|c|c|c|c|c|c|c|c|c|c|c|}
\hline $\mathrm{C}-\mathrm{V}$ & $\mathrm{V} 1$ & $\mathrm{~V} 2$ & V3 & $\mathrm{V} 4$ & V5 & V6 & V7 & V8 & V9 & V10 \\
\hline $\mathrm{C} 1$ & 25 & 60 & - & - & 9 & 10 & - & - & - & 41 \\
\hline $\mathrm{C} 2$ & 36 & 33 & 21 & 33 & 16 & 23 & - & 34 & - & 17 \\
\hline C3 & 22 & 52 & 58 & 30 & 46 & 27 & 42 & 24 & - & 23 \\
\hline $\mathrm{C} 4$ & - & - & - & 30 & 32 & 39 & 76 & 53 & 55 & 25 \\
\hline C5 & 21 & 39 & 53 & 24 & 57 & - & 39 & 27 & - & 10 \\
\hline C6 & - & 37 & - & 35 & 82 & - & - & - & - & 30 \\
\hline C7 & - & - & 75 & 57 & 62 & 33 & - & - & - & 41 \\
\hline C8 & 29 & 48 & 22 & 22 & 30 & 19 & 63 & 35 & - & 17 \\
\hline C9 & 26 & 26 & - & 28 & - & 29 & - & - & - & 17 \\
\hline $\mathrm{C} 10$ & 56 & 48 & - & 44 & 20 & - & 73 & 56 & 40 & 29 \\
\hline C11 & - & 42 & - & - & - & 33 & - & - & 70 & - \\
\hline $\mathrm{C} 12$ & 28 & 28 & - & - & - & - & 52 & 29 & 31 & 21 \\
\hline C13 & 11 & 32 & - & 19 & - & - & - & - & 12 & 23 \\
\hline C14 & 20 & 47 & - & 15 & 28 & 23 & 27 & 16 & - & 25 \\
\hline C15 & 14 & 27 & - & 16 & - & 32 & - & - & 18 & 11 \\
\hline C16 & 11 & 32 & - & - & - & - & - & - & - & 34 \\
\hline$n$ & 299 & 551 & 229 & 353 & 382 & 268 & 372 & 274 & 226 & 364 \\
\hline
\end{tabular}

$n$ shows the number of occurrences of $\mathrm{C}_{i}$ to $\mathrm{V}_{j}$. 
TABLE 5: A-C connections of the post-60s traditional village tourists (cutoff point $=50 \%$ ).

\begin{tabular}{lccc}
\hline A-C & A1 & A3 & A5 \\
\hline C1 & - & $65 / 95(68.4 \%)$ & - \\
C5 & $54 / 88(61.4 \%)$ & - & - \\
C6 & $55 / 88(62.5 \%)$ & - & - \\
C7 & - & - & $48 / 96(50.6 \%)$ \\
\hline
\end{tabular}

Percentage $=n / N$, where $N$ is the total number of respondents recognizing an $\mathrm{A}\left(\mathrm{A}_{i}\right)$ and $n$ is the number of respondents agreeing that $\mathrm{A}\left(\mathrm{A}_{i}\right)$ can produce a $\mathrm{C}$ $\left(\mathrm{C}_{i}\right)$.

TABLE 6: C-V connections of the post-60s traditional village tourists (cutoff point $=50 \%$ ).

\begin{tabular}{lcccc}
\hline $\mathrm{C}-\mathrm{V}$ & $\mathrm{V} 2$ & $\mathrm{~V} 3$ & $\mathrm{~V} 5$ & \\
\hline $\mathrm{C} 1$ & $60 / 75(80.0 \%)$ & - & - & $\mathrm{V} 10$ \\
$\mathrm{C} 5$ & - & $53 / 104(51.0 \%)$ & $57 / 104(54.8 \%)$ & $41 / 75(54.7 \%)$ \\
C6 & - & - & $82 / 103(79.6 \%)$ & - \\
C7 & - & $75 / 122(61.5 \%)$ & $62 / 12(50.8 \%)$ & - \\
\hline
\end{tabular}

Percentage $=n / N$, where $N$ is the total number of respondents recognizing a $\mathrm{C}\left(\mathrm{C}_{i}\right)$ and $n$ is the number of respondents agreeing that $\mathrm{C}\left(\mathrm{C}_{i}\right)$ can reflect a $\mathrm{V}\left(\mathrm{V}_{i}\right)$.

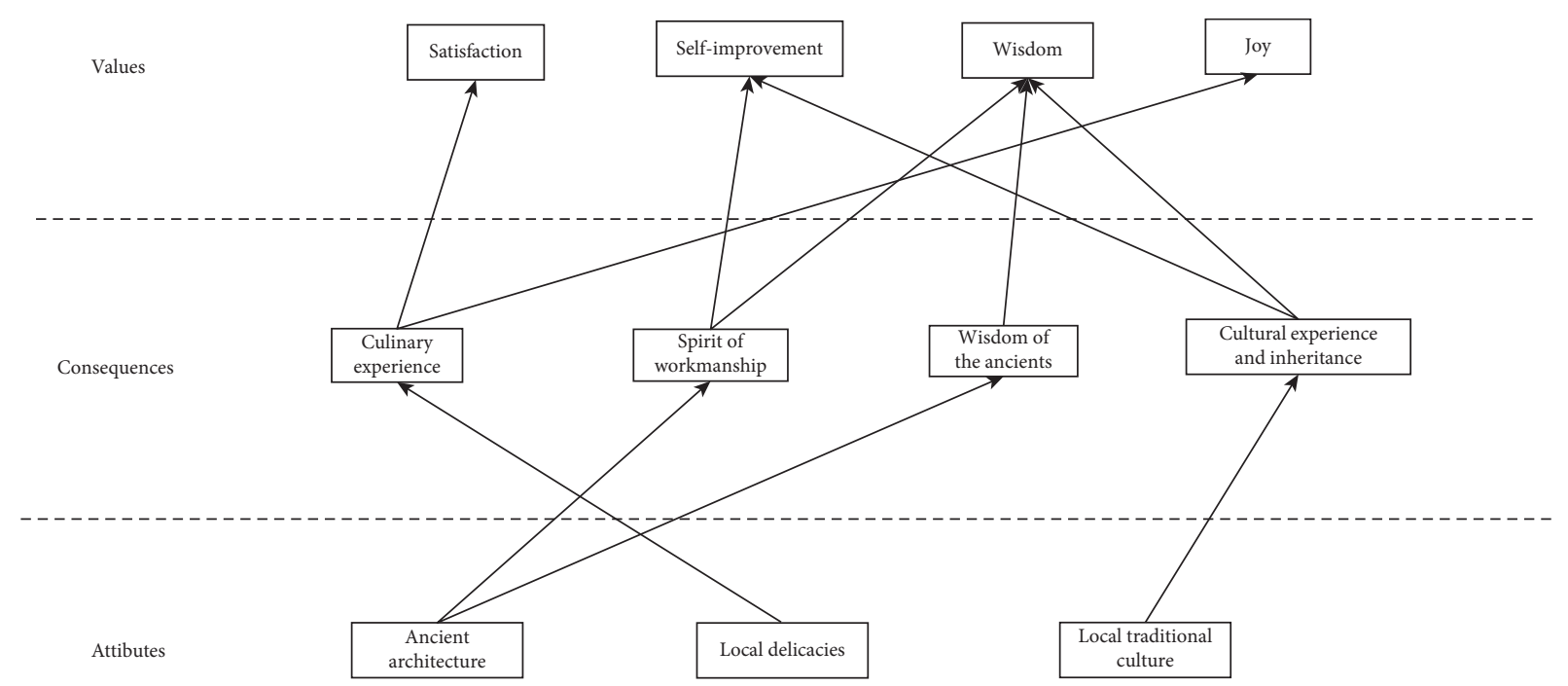

FIgURE 1: The HVM of the post-60s tourists to traditional villages (including correlated factors only) (cutoff point $=50 \%$ ).

According to relevant literature, $50 \%$ cut-off point is used to construct HVM diagram, including two aspects: 1 . If the total number of respondents choosing $\mathrm{A}, \mathrm{C}$, or $\mathrm{V}$ is less than $50 \%$ (i.e., 75 respondents), $50 \%$ is lower than the cut-off point. 2. The proportion of association relationship in A-C matrix, $N_{\mathrm{C} j} / N_{\mathrm{A} i}$, is lower than $50 \%$, and it is also lower than $50 \%$ of the cut-off point. The above two cases are not identified in the HVM diagram, and only the association relationship above $50 \%$ is listed in the HVM diagram to improve the typicality of MEC chain. For example, only A1, A3, A4, and A5 have more than 75 respondents selected for attribute A, so other attributes are not marked in the HVM diagram. The value of $N_{\mathrm{C} j} / N_{\mathrm{A} i}$ greater than $50 \%$ is $\mathrm{C} 1$ (A3$\mathrm{C} 1), \mathrm{C} 5$ (A1-C5), C6 (A1-C6), C7 (A5-C7). Other paths are not marked.

The $\mathrm{V}$ of job comes from the pursuit of the post-60s tourists for the A of local delicacies and the $\mathrm{C}$ of culinary experience. In traditional Chinese culture, food is the paramount necessity of the people. Since the beginning of the 21 st century, gourmet tourism has become the main travel motive for tourists $[77,78]$. Tourists perceive the culture of destinations by experiencing food, which affects the travel experience [79]. Through the culinary experience of enjoying local delicacies, the post-60s tourists gain physical and psychological Vs like joy and satisfaction (local delicacies-culinary experience-satisfaction).

HVM results show that the $\mathrm{V}$ of wisdom stems from the pursuit of the post-60s tourists for spirit of workmanship, wisdom of the ancients, and cultural experience and inheritance. For those born in the 1960s, the traditional culture of rural tourism destinations can bring them cultural experience, and the ancient buildings can help them appreciate the craftsman spirit and the wisdom of the ancients, which are conducive to enhancing their cultural identity and acquiring more knowledge. The post-60s tourists are nurtured by traditional Chinese culture. Patriotism and heroism are their typical values [80]. Our findings are consistent with the literature. The nostalgic feelings encourage them to travel to traditional villages. Traveling through the ancient architecture, the tourists perceive the wisdom of the ancients in 
planning and design and the spirit of workmanship exemplified by the builders. Such an experience satisfies their pursuit of the $\mathrm{V}$ of wisdom.

In addition, the post-80s tourists, like those born in the 1970s, realize the $\mathrm{V}$ of sense of belonging through the pursuit of the A of local traditional culture and the $\mathrm{C}$ of cultural experience, and inheritance exploration and learning are important motives for tourists [81]. Apart from the spirit of workmanship, the post-60s tourists learn the knowledge about traditional culture and ancient architecture and broaden their horizons [82-84]. In this way, they realize the $\mathrm{V}$ of self-improvement.

\subsection{MEC Value Chains of the Post-70s Traditional Village} Tourists. A total of 150 post-70s tourists were surveyed. According to the survey data, two interconnected matrices were set up for the A-C connections (Table 7) and $\mathrm{C}-\mathrm{V}$ connections (Table 8) selected by these respondents. The number of A-C connections (Table 9) and $\mathrm{C}-\mathrm{V}$ connections (Table 10) being selected by the respondents was counted and used to prepare the HVM for the MEC value chains (A$\mathrm{C}-\mathrm{V}$ ) of the post-70s tourists (Figure 2).

It can be observed that the post-70s tourists pursue five As (ancient architecture, environment of traditional village, natural landscape around traditional village, local traditional culture, and local delicacies), six Cs (wisdom of the ancients, ecological protection, idyllic life, picturesque landscape, cultural experience and inheritance, and culinary experience), and seven Vs (wisdom, beautiful world, inner harmony, self-improvement, satisfaction, joy, and sense of belonging), which constitute eleven MEC value chains.

Like the post-60s tourists, the post-70s tourists realize the Vs of satisfaction and joy through the pursuit of the A of local delicacies and the $\mathrm{C}$ of culinary experience.

The V of wisdom stems from the pursuit of the post-70s tourists for the A of ancient architecture and the $\mathrm{C}$ of wisdom of the ancients. Going through the reform and opening-up, the post-70s tourists experienced the enrollment expansion of colleges and employment. Through diligent learning and hard work, these tourists achieved their goals of work, income, and life [85]. As a result, they generally believe in "knowledge can change your fate." Meanwhile, the post-70s tourists are deeply influenced by traditional culture in society and family. Therefore, they pay more attention to the $\mathrm{V}$ of wisdom embodied in ancient architecture, during travel to traditional villages.

The V of self-improvement originates from the pursuit of the post-70s tourists for the A of local traditional culture and the $\mathrm{C}$ of cultural experience and inheritance. The Chinese education advocates "reading ten thousand books and traveling ten thousand miles." Both reading and traveling are important for human development. Traveling can improve the capacity of the tourists [86] and sublimate the inner motives to higher needs, thereby promoting personal development [87]. The post-70s tourists believe that, through traditional village tourism, they can fully and deeply understand and recognize local traditional culture and customs, acquire new knowledge, broaden their
TABLE 7: C motives of the post-70s traditional village tourists.

\begin{tabular}{lcccccccccccc}
\hline A-C & A1 & A2 & A3 & A4 & A5 & A6 & A7 & A8 & A9 & A10 & A11 & $n$ \\
\hline C1 & - & - & 89 & - & - & - & - & 6 & 25 & - & - & 120 \\
C2 & 24 & 27 & - & 26 & 19 & 9 & - & 2 & - & 27 & 34 & 168 \\
C3 & 31 & 17 & 34 & 19 & 48 & 9 & 22 & 4 & 13 & 17 & 14 & 228 \\
C4 & 22 & 29 & 18 & 54 & 24 & 6 & 13 & 3 & 5 & 20 & 39 & 233 \\
C5 & 38 & 15 & - & 14 & 20 & 21 & 7 & 2 & 6 & 29 & 6 & 158 \\
C6 & 50 & 23 & 16 & 22 & 35 & 23 & 19 & 3 & 8 & 31 & 11 & 241 \\
C7 & 23 & 16 & 18 & 30 & 63 & 11 & 27 & 4 & 8 & 24 & 17 & 241 \\
C8 & 15 & 23 & - & 40 & 18 & - & - & 2 & - & 12 & 58 & 168 \\
C9 & 7 & 10 & - & - & 13 & 5 & 5 & 1 & - & - & 10 & 51 \\
C10 & 19 & 30 & 34 & 50 & 28 & 3 & 34 & 4 & 14 & 22 & 44 & 282 \\
C11 & 11 & 15 & 11 & 25 & 6 & 4 & 8 & 3 & 1 & 12 & 17 & 113 \\
C12 & 8 & 17 & 9 & 19 & 10 & 9 & 6 & 1 & 5 & 10 & 26 & 120 \\
C13 & - & - & 13 & 6 & - & - & 1 & 1 & 28 & - & - & 49 \\
C14 & 15 & 13 & 29 & 12 & 29 & 4 & 26 & 5 & 12 & 16 & 8 & 169 \\
C15 & 8 & 6 & - & 13 & 9 & - & 29 & - & 6 & 8 & - & 79 \\
C16 & 10 & 11 & 23 & 15 & 15 & 2 & 7 & 1 & 14 & 13 & 21 & 132 \\
\hline
\end{tabular}

$n$ is the number of connections.

TABLE 8: V motives of the post-70s traditional village tourists.

\begin{tabular}{lcccccccccc}
\hline C-V & V1 & V2 & V3 & V4 & V5 & V6 & V7 & V8 & V9 & V10 \\
\hline C1 & 34 & 78 & - & - & 17 & 16 & - & - & - & 56 \\
C2 & 65 & 35 & 33 & 35 & 28 & 25 & - & 35 & - & 26 \\
C3 & 33 & 49 & 69 & 29 & 37 & 17 & 37 & 20 & - & 26 \\
C4 & - & - & - & 33 & 33 & 40 & 86 & 46 & 56 & 32 \\
C5 & 23 & 27 & 48 & 23 & 58 & - & 31 & 30 & - & 16 \\
C6 & - & 41 & - & 36 & 86 & - & - & - & - & 32 \\
C7 & - & - & 74 & 61 & 57 & 28 & - & - & - & 42 \\
C8 & 46 & 29 & 22 & 26 & 11 & 16 & 87 & 41 & - & 33 \\
C9 & 21 & 11 & - & 16 & - & 13 & - & - & - & 13 \\
C10 & 61 & 37 & - & 45 & 21 & - & 67 & 45 & 33 & 41 \\
C11 & - & 34 & - & - & - & 27 & - & - & 50 & - \\
C12 & 31 & 23 & - & - & - & - & 51 & 27 & 27 & 28 \\
C13 & 17 & 25 & - & 10 & - & - & - & - & 8 & 24 \\
C14 & 36 & 53 & - & 32 & 23 & 23 & 24 & 20 & - & 40 \\
C15 & 21 & 28 & - & 24 & - & 22 & - & - & 27 & 18 \\
C16 & 15 & 49 & - & - & - & - & - & - & - & 46 \\
$n$ & 403 & 519 & 246 & 370 & 371 & 227 & 383 & 264 & 201 & 473 \\
\hline
\end{tabular}

$n$ is the number of connections.

horizons, and gain experience. In other words, travel to traditional villages both enriches their lives and increases their knowledge [82-84], thus helping them realize the $\mathrm{V}$ of self-improvement. At the same time, the post-70s tourists have a higher spiritual demand for traditional culture [88]. They personally feel the importance of inheriting local traditional culture to the development of the Chinese culture. This feeling results in the confidence in their culture, and a strong sense of belonging (local traditional culture-cultural experience and inheritance-sense of belonging).

The $\mathrm{V}$ of beautiful world derives from the post-70s tourists' pursuit of the As of environment of traditional village and natural landscape around traditional village and the Cs of ecological protection, idyllic life, and picturesque landscape. In traditional Chinese culture, nature is the source of human life, and tourism bridges human and nature [89]. Besides, traditional Chinese philosophy emphasizes 
TABLE 9: A-C connections of the post-70s traditional village tourists (cutoff point $=50 \%$ ).

\begin{tabular}{lcccccc}
\hline A-C & A1 & A3 & A4 & A5 & A9 \\
\hline C1 & - & $89 / 104(85.6 \%)$ & - & - & - & A11 \\
C4 & - & - & - & $54 / 94(57.4 \%)$ & - & - \\
C6 & $50 / 78(64.1 \%)$ & - & - & - & - & - \\
C7 & - & - & - & $63 / 107(58.9 \%)$ & - & - \\
C8 & - & - & $50 / 94(53.2 \%)$ & - & - & - \\
C10 & - & & - & - & $48 / 87(66.7 \%)$ \\
\hline
\end{tabular}

Percentage $=n / N$, where $N$ is the total number of respondents recognizing an $\mathrm{A}\left(\mathrm{A}_{i}\right)$ and $n$ is the number of respondents agreeing that $\mathrm{A}\left(\mathrm{A}_{i}\right)$ can produce a C $\left(\mathrm{C}_{i}\right)$.

TABLE 10: C-V connections of the post-70s traditional village tourists (cutoff point $=50 \%$ ).

\begin{tabular}{|c|c|c|c|c|c|c|c|}
\hline $\mathrm{C}-\mathrm{V}$ & V1 & $\mathrm{V} 2$ & V3 & V4 & V5 & V7 & V10 \\
\hline $\mathrm{C} 1$ & - & $78 / 99(78.8 \%)$ & - & - & - & - & $56 / 99(56.6 \%)$ \\
\hline $\mathrm{C} 4$ & - & - & - & - & - & $86 / 116(74.1 \%)$ & - \\
\hline C5 & - & - & - & - & $58 / 101(57.4 \%)$ & - & - \\
\hline C6 & - & - & - & - & $86 / 109(78.9 \%)$ & - & - \\
\hline $\mathrm{C} 7$ & - & - & $74 / 118(62.7 \%)$ & $61 / 118(51.7 \%)$ & - & - & - \\
\hline $\mathrm{C} 8$ & - & - & - & - & - & $87 / 103(84.5 \%)$ & - \\
\hline $\mathrm{C} 10$ & $61 / 117(52.1 \%)$ & - & - & - & - & $67 / 117(57.3 \%)$ & - \\
\hline
\end{tabular}

Percentage $=n / N$, where $N$ is the total number of respondents recognizing a $\mathrm{C}\left(\mathrm{C}_{i}\right)$ and $n$ is the number of respondents agreeing that $\mathrm{C}\left(\mathrm{C}_{i}\right)$ can reflect a $\mathrm{V}\left(\mathrm{V}_{i}\right)$.

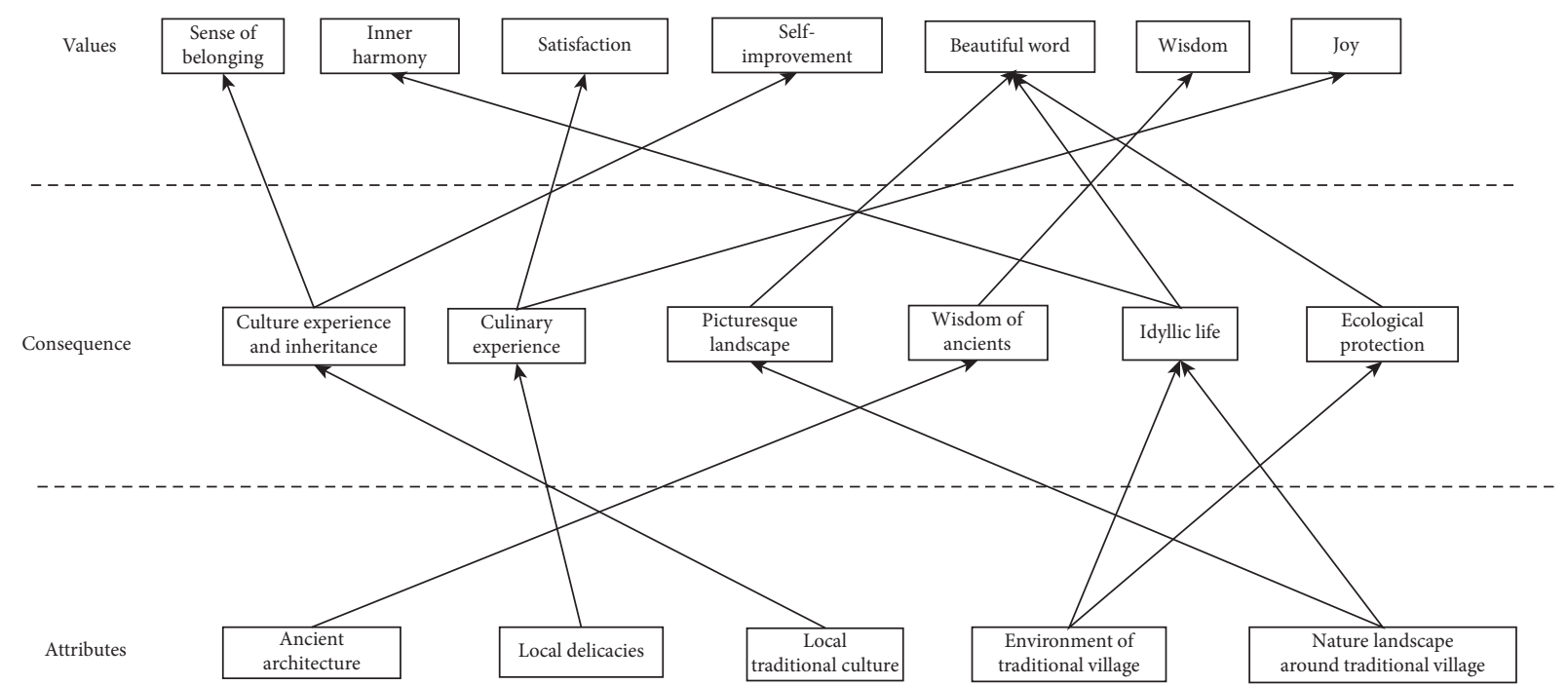

FIGURE 2: The HVM of the post-70s tourists to traditional villages (including correlated factors only) (cutoff point $=50 \%$ ).

that the harmony between human and nature, human and society, and body and soul can promote spiritual cultivation [90]. The environment, surrounding natural landscape, and idyllic life of traditional villages reflect the philosophy of ecological protection and produce a beautiful environment with a picturesque landscape, which satisfies the appreciation and love of the post-70s tourists for human-nature harmony and beautiful sceneries, as well as their pursuit of a beautiful world $[82,83,91,92]$. Traveling in such a picturesque landscape helps to cultivate their spirits.

Most post-70s tourists live in cities. They long to temporarily escape from the environment of daily life and work [93]. The tranquil environment (environment of traditional village-idyllic life-inner harmony) and natural landscape (natural landscape around traditional village-idyllic life-inner harmony) of traditional villages can relieve the pressure of work and life [94] and ensure the harmony between human and nature [95], realizing the $\mathrm{V}$ of inner harmony.

4.3. MEC Value Chains of the Post-80s Traditional Village Tourists. A total of 150 post-80s tourists were surveyed. According to the survey data, two interconnected matrices were set up for the A-C connections (Table 11) and $\mathrm{C}-\mathrm{V}$ connections (Table 12) selected by these respondents. The number of A-C connections (Table 13) and C-V connections (Table 14) being selected by the respondents was counted and used to prepare the HVM for the MEC value chains (A$\mathrm{C}-\mathrm{V}$ ) of post-60s tourists (Figure 3 ). 
TABLE 11: C motives of post-80s traditional village tourists.

\begin{tabular}{|c|c|c|c|c|c|c|c|c|c|c|c|c|}
\hline $\mathrm{A}-\mathrm{C}$ & A1 & A2 & A3 & A4 & A5 & A6 & A7 & A8 & A9 & A10 & A11 & $n$ \\
\hline $\mathrm{C} 1$ & - & - & 93 & - & - & - & - & 4 & 46 & - & - & 143 \\
\hline $\mathrm{C} 2$ & 37 & 23 & - & 29 & 17 & 10 & - & 3 & - & 18 & 32 & 169 \\
\hline C3 & 31 & 21 & 29 & 25 & 47 & 14 & 16 & 5 & 13 & 25 & 23 & 249 \\
\hline $\mathrm{C} 4$ & 30 & 38 & 15 & 54 & 21 & 2 & 23 & 5 & 9 & 17 & 47 & 261 \\
\hline C5 & 51 & 14 & - & 15 & 14 & 11 & 8 & 2 & 10 & 23 & 7 & 155 \\
\hline C6 & 40 & 25 & 16 & 21 & 41 & 15 & 16 & 3 & 8 & 23 & 13 & 221 \\
\hline C7 & 38 & 26 & 25 & 29 & 75 & 19 & 23 & 9 & 21 & 22 & 16 & 303 \\
\hline C8 & 18 & 28 & - & 42 & 17 & - & - & 5 & - & 14 & 49 & 173 \\
\hline C9 & 5 & 11 & - & - & 11 & - & 6 & 3 & - & - & 10 & 46 \\
\hline $\mathrm{C} 10$ & 21 & 27 & 31 & 57 & 24 & 4 & 42 & 6 & 16 & 18 & 40 & 286 \\
\hline $\mathrm{C} 11$ & 9 & 18 & 22 & 23 & 9 & 1 & 13 & 2 & 6 & 12 & 26 & 141 \\
\hline $\mathrm{C} 12$ & 15 & 20 & 16 & 27 & 11 & 2 & 10 & 4 & 5 & 8 & 36 & 154 \\
\hline $\mathrm{C} 13$ & - & - & 23 & 4 & - & - & 6 & 2 & 36 & - & - & 71 \\
\hline $\mathrm{C} 14$ & 23 & 13 & 28 & 11 & 20 & 2 & 16 & 10 & 16 & 9 & 11 & 159 \\
\hline $\mathrm{C} 15$ & 21 & 10 & - & 24 & 20 & 3 & 26 & 3 & 7 & 15 & - & 129 \\
\hline $\mathrm{C} 16$ & 23 & 12 & 44 & 24 & 11 & 7 & 9 & 5 & 16 & 15 & 29 & 195 \\
\hline
\end{tabular}

$n$ is the number of connections.

TABLE 12: $\mathrm{V}$ motives of post-80s traditional village tourists.

\begin{tabular}{|c|c|c|c|c|c|c|c|c|c|c|}
\hline $\mathrm{C}-\mathrm{V}$ & $\mathrm{V} 1$ & $\mathrm{~V} 2$ & V3 & $\mathrm{V} 4$ & V5 & V6 & V7 & V8 & V9 & V10 \\
\hline $\mathrm{C} 1$ & 31 & 90 & - & - & 10 & 17 & - & - & - & 73 \\
\hline $\mathrm{C} 2$ & 60 & 25 & 29 & 41 & 19 & 20 & - & 31 & - & 36 \\
\hline C3 & 32 & 42 & 78 & 21 & 51 & 19 & 37 & 19 & - & 25 \\
\hline $\mathrm{C} 4$ & - & - & - & 34 & 22 & 37 & 85 & 53 & 53 & 30 \\
\hline C5 & 28 & 32 & 49 & 21 & 69 & - & 35 & 19 & - & 19 \\
\hline C6 & - & 30 & - & 50 & 96 & - & - & - & - & 30 \\
\hline C7 & - & - & 83 & 66 & 69 & 40 & - & - & - & 38 \\
\hline C8 & 61 & 37 & 22 & 22 & 14 & 26 & 88 & 37 & - & 48 \\
\hline C9 & 14 & 17 & - & 16 & - & 19 & - & - & - & 15 \\
\hline $\mathrm{C} 10$ & 54 & 62 & - & 55 & 15 & - & 84 & 51 & 26 & 50 \\
\hline C11 & - & 33 & - & - & - & 37 & - & - & 66 & - \\
\hline C12 & 38 & 27 & - & - & - & - & 69 & 30 & 35 & 35 \\
\hline $\mathrm{C} 13$ & 8 & 43 & - & 9 & - & - & - & - & 12 & 37 \\
\hline C14 & 21 & 51 & - & 20 & 27 & 23 & 35 & 21 & - & 43 \\
\hline C15 & 27 & 37 & - & 37 & - & 50 & - & - & 31 & 32 \\
\hline C16 & 25 & 66 & - & - & - & - & - & - & - & 70 \\
\hline$n$ & 399 & 592 & 261 & 392 & 392 & 288 & 433 & 261 & 223 & 581 \\
\hline
\end{tabular}

$n$ is the number of connections.

TABLE 13: A-C connections of post-80s traditional village tourists (cutoff point $=50 \%$ ).

\begin{tabular}{|c|c|c|c|c|c|c|}
\hline $\mathrm{A}-\mathrm{C}$ & A1 & $\mathrm{A} 2$ & A3 & A4 & A5 & A11 \\
\hline $\mathrm{C} 1$ & - & - & $93 / 112(83.0 \%)$ & - & - & - \\
\hline $\mathrm{C} 4$ & - & $38 / 76(50.0 \%)$ & - & $54 / 102(52.9 \%)$ & - & - \\
\hline C5 & $51 / 93(54.8 \%)$ & - & - & - & - & - \\
\hline $\mathrm{C} 7$ & - & - & - & - & 75/113 (66.4\%) & - \\
\hline $\mathrm{C} 8$ & - & - & - & - & - & $49 / 84(58.3 \%)$ \\
\hline $\mathrm{C} 10$ & - & - & - & $57 / 102(55.9 \%)$ & - & - \\
\hline
\end{tabular}

Percentage $=n / N$, where $N$ is the total number of respondents recognizing an $\mathrm{A}\left(\mathrm{A}_{i}\right)$ and $n$ is the number of respondents agreeing that $\mathrm{A}\left(\mathrm{A}_{i}\right)$ can produce a $\mathrm{C}\left(\mathrm{C}_{i}\right)$.

It can be observed that the post-80s tourists pursue six As (ancient architecture, local traditional culture, environment of traditional village, natural landscape around traditional village, water system of traditional village, and local delicacies), six Cs (spirit of workmanship, cultural experience and inheritance, ecological protection, idyllic life, picturesque landscape, and culinary experience), and seven Vs (wisdom, beautiful world, inner harmony, self-improvement, satisfaction, joy, and sense of belonging), which constitute seven MEC value chains.

Like the post-60s and post-70s tourists, the post-80s tourists realize the Vs of satisfaction and joy through the pursuit of the A of local delicacies and the $\mathrm{C}$ of culinary experience. 
TABLE 14: C-V connections of post-80s traditional village tourists (cutoff point $=50 \%$ ).

\begin{tabular}{|c|c|c|c|c|c|c|c|}
\hline $\mathrm{C}-\mathrm{V}$ & V1 & $\mathrm{V} 2$ & V3 & V4 & V5 & V7 & V10 \\
\hline $\mathrm{C} 1$ & - & $90 / 103(87.4 \%)$ & - & - & - & - & $73 / 103(70.9 \%)$ \\
\hline $\mathrm{C} 4$ & - & - & - & - & - & $85 / 121(70.2 \%)$ & - \\
\hline C5 & - & - & - & - & $69 / 107(64.5 \%)$ & - & - \\
\hline $\mathrm{C} 7$ & - & - & $83 / 130(63.8 \%)$ & $66 / 130(50.8 \%)$ & $69 / 130(53.1 \%)$ & - & - \\
\hline $\mathrm{C} 8$ & $61 / 111(55.0 \%)$ & - & - & - & - & $88 / 111(79.3 \%)$ & - \\
\hline $\mathrm{C} 10$ & - & $62 / 123(50.4 \%)$ & - & - & - & $84 / 123(68.3 \%)$ & - \\
\hline
\end{tabular}

Percentage $=n / N$, where $N$ is the total number of respondents recognizing a $\mathrm{C}\left(\mathrm{C}_{i}\right)$ and $n$ is the number of respondents agreeing that $\mathrm{C}\left(\mathrm{C}_{i}\right)$ can reflect a $\mathrm{V}\left(\mathrm{V}_{i}\right)$.

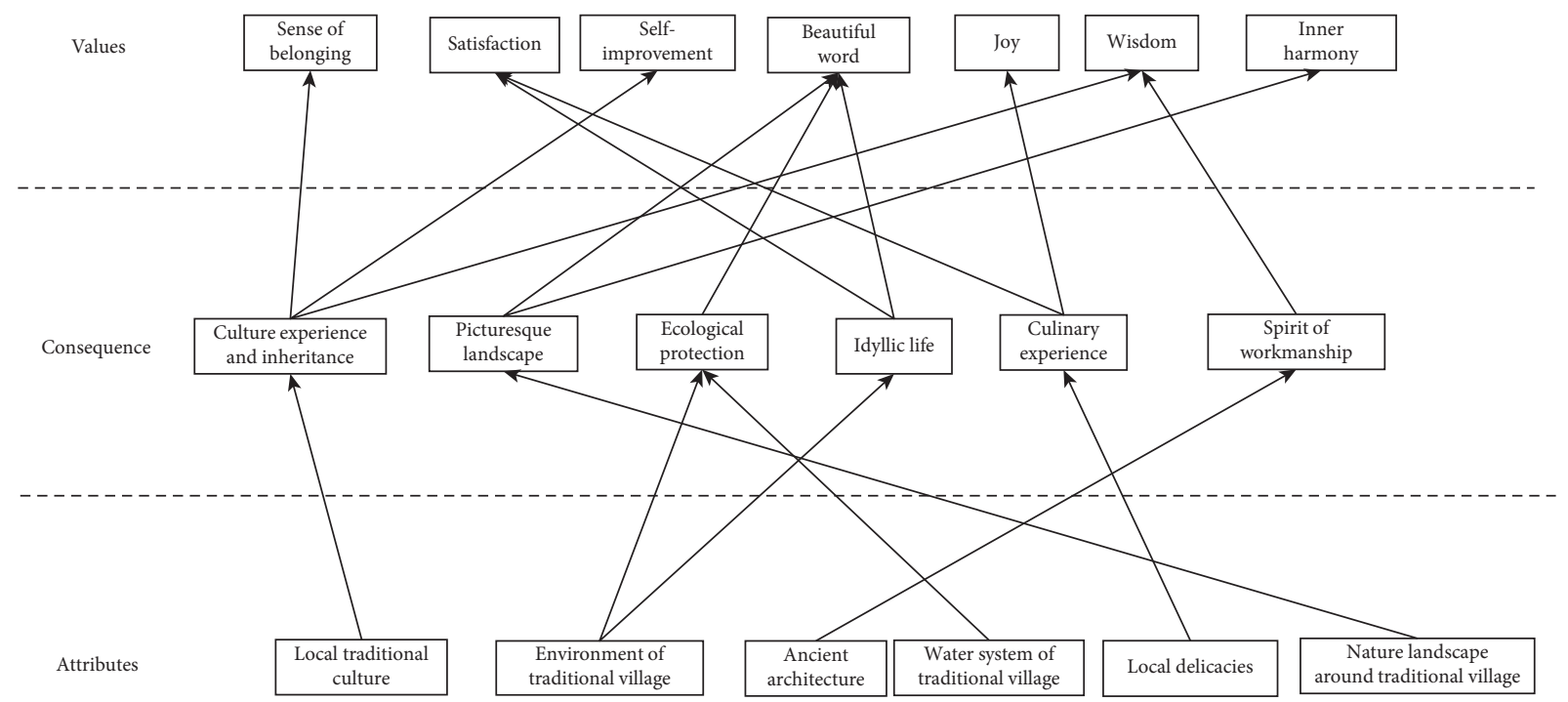

FIGURE 3: The HVM of post-80s tourists to traditional villages (including correlated factors only) (cutoff point $=50 \%$ ).

The $\mathrm{V}$ of wisdom comes from the pursuit of the post-80s tourists for the As of ancient architecture and local traditional culture and the Cs of spirit of workmanship and cultural experience and inheritance. The post-80s tourists have the same Vs as the post-60s and post-70s tourists but differ from the latter in As and Cs.

The post-80s tourists achieved personal success through hard work and diligent learning [96]. Like the post-70s tourists, they believe that knowledge has the power to change one's fate and are deeply influenced by traditional culture. During travel through traditional villages, the post-80s tourists highlight the $\mathrm{V}$ of wisdom reflected by the spirit of workmanship among the builders of ancient architecture and perceive the $\mathrm{V}$ of wisdom of the ancestors of the Chinese nation in the creation and inheritance of the traditional culture.

In addition, the post-80s and post-70s tourists both realize the value of "belonging" (V4) by pursuing the attribute of "local traditional culture" (A5) and the result of "cultural experience and inheritance" (C7). In other words, the post-80s and post-70s tourists share the same MEC value chain $(\mathrm{A} 5 \longrightarrow \mathrm{C} 7 \longrightarrow \mathrm{V} 4)$. Similarly, tourists born in the $60 \mathrm{~s}$ and 70s have realized the value of "self-improvement" (V3) by pursuing the attribute of "local traditional culture" (A5) and the result of "cultural experience and inheritance" (C7). The post-60s and post-70s share the same MEC value chain $(\mathrm{A} 5 \longrightarrow \mathrm{C} 7 \longrightarrow \mathrm{V} 3)$.
The $\mathrm{V}$ of beautiful world stems from the post-80s tourists' pursuit of the As of environment of traditional village, natural landscape around traditional village, and water system of traditional village, as well as the Cs of ecological protection, idyllic life, and picturesque landscape. In their views, the water system, environment, and surrounding natural landscape of traditional villages, plus the idyllic life of residents, protect the eco-environment and nurture a beautiful environment with picturesque landscape, providing them with the chance to realize the $\mathrm{V}$ of beautiful world [82, 83, 91, 92]. Hence, the post-80s tourists can cultivate their spirit by traveling to traditional villages.

The post-80s tourists share the same motive of escaping from daily routines as the post-70s tourists [93]. The environment of traditional village and natural landscape around traditional village (environment of traditional village-idyllic life-inner harmony; natural landscape around traditional village - picturesque landscape - inner harmony) set the stage for an idyllic life in the picturesque landscape, which relieves pressure [94] and realizes the $\mathrm{V}$ of inner harmony.

\subsection{MEC Value Chains of the Post-90s Traditional Village} Tourists. A total of 150 post-90s tourists were surveyed. According to the survey data, two interconnected matrices were set up for the A-C connections (Table 15) and C-V connections (Table 16) selected by these respondents. The 
TABLE 15: C motives of post-90s traditional village tourists.

\begin{tabular}{|c|c|c|c|c|c|c|c|c|c|c|c|c|}
\hline A-C & A1 & A2 & A3 & A4 & A5 & A6 & A7 & A8 & A9 & A10 & A11 & $n$ \\
\hline $\mathrm{C} 1$ & - & - & 96 & - & - & - & - & 1 & 40 & - & - & 137 \\
\hline $\mathrm{C} 2$ & 31 & 20 & - & 33 & 15 & 2 & - & 6 & - & 19 & 37 & 163 \\
\hline C3 & 37 & 20 & 31 & 31 & 47 & 9 & 30 & 5 & 12 & 23 & 16 & 261 \\
\hline $\mathrm{C} 4$ & 26 & 30 & 11 & 60 & 25 & 4 & 22 & 7 & 7 & 23 & 39 & 254 \\
\hline C5 & 48 & 12 & - & 22 & 24 & 7 & 12 & 4 & 7 & 32 & 8 & 176 \\
\hline C6 & 37 & 15 & 18 & 33 & 40 & 14 & 26 & 3 & 8 & 35 & 18 & 247 \\
\hline C7 & 37 & 31 & 23 & 35 & 65 & 8 & 31 & 11 & 12 & 26 & 19 & 298 \\
\hline C8 & 11 & 27 & - & 37 & 15 & - & - & 8 & - & 18 & 61 & 177 \\
\hline C9 & 6 & 7 & - & - & 15 & 1 & 10 & 6 & - & - & 9 & 54 \\
\hline C10 & 27 & 31 & 35 & 49 & 19 & 4 & 46 & 7 & 18 & 25 & 54 & 315 \\
\hline $\mathrm{C} 11$ & 15 & 15 & 24 & 33 & 14 & 3 & 21 & 4 & 11 & 14 & 18 & 172 \\
\hline C12 & 16 & 20 & 18 & 38 & 14 & 3 & 22 & 1 & 8 & 16 & 32 & 188 \\
\hline C13 & - & - & 18 & 13 & - & - & 8 & 6 & 32 & - & - & 77 \\
\hline C14 & 18 & 14 & 27 & 16 & 35 & 4 & 16 & 6 & 17 & 13 & 14 & 180 \\
\hline C15 & 22 & 11 & - & 20 & 12 & 2 & 24 & 3 & 5 & 10 & - & 109 \\
\hline $\mathrm{C} 16$ & 20 & 18 & 43 & 23 & 23 & 5 & 20 & 8 & 14 & 21 & 36 & 231 \\
\hline
\end{tabular}

$n$ is the number of connections.

TABLE 16: V motives of post-90s traditional village tourists.

\begin{tabular}{|c|c|c|c|c|c|c|c|c|c|c|}
\hline $\mathrm{C}-\mathrm{V}$ & $\mathrm{V} 1$ & $\mathrm{~V} 2$ & $\mathrm{~V} 3$ & $\mathrm{~V} 4$ & V5 & V6 & V7 & V8 & V9 & V10 \\
\hline $\mathrm{C} 1$ & 31 & 88 & - & - & 18 & 15 & - & - & - & 69 \\
\hline $\mathrm{C} 2$ & 51 & 41 & 37 & 29 & 27 & 26 & - & 33 & - & 32 \\
\hline C3 & 39 & 62 & 81 & 27 & 52 & 34 & 34 & 17 & - & 33 \\
\hline $\mathrm{C} 4$ & - & - & - & 33 & 37 & 41 & 79 & 55 & 54 & 39 \\
\hline C5 & 31 & 34 & 53 & 28 & 75 & - & 28 & 20 & - & 20 \\
\hline C6 & - & 51 & - & 47 & 95 & - & - & - & - & 32 \\
\hline C7 & - & - & 95 & 61 & 73 & 42 & - & - & - & 51 \\
\hline C8 & 45 & 35 & 30 & 23 & 27 & 25 & 85 & 48 & - & 40 \\
\hline C9 & 23 & 16 & - & 21 & - & 22 & - & - & - & 16 \\
\hline $\mathrm{C} 10$ & 66 & 46 & - & 52 & 25 & - & 82 & 58 & 36 & 50 \\
\hline C11 & - & 50 & - & - & - & 47 & - & - & 62 & - \\
\hline $\mathrm{C} 12$ & 30 & 41 & - & - & - & - & 70 & 43 & 33 & 49 \\
\hline $\mathrm{C} 13$ & 19 & 38 & - & 16 & - & - & - & - & 14 & 35 \\
\hline $\mathrm{C} 14$ & 26 & 51 & - & 26 & 30 & 19 & 36 & 23 & - & 44 \\
\hline C15 & 25 & 33 & - & 31 & - & 33 & - & - & 32 & 35 \\
\hline C16 & 28 & 68 & - & - & - & - & - & - & - & 65 \\
\hline$n$ & 414 & 654 & 296 & 394 & 459 & 304 & 414 & 297 & 231 & 610 \\
\hline
\end{tabular}

$n$ is the number of connections.

number of A-C connections (Table 17) and C-V connections (Table 18) being selected by the respondents was counted and used to prepare the HVM for the MEC value chains (A$\mathrm{C}-\mathrm{V}$ ) of post-90s tourists (Figure 4).

It can be observed that the post-90s tourists pursue six As (ancient architecture, local traditional culture, environment of traditional village, natural landscape around traditional village, lifestyle of residents, and local delicacies), six Cs (spirit of workmanship, cultural experience and inheritance, ecological protection, picturesque landscape, idyllic life, and culinary experience), and six Vs (wisdom, beautiful world, inner harmony, self-improvement, satisfaction, and joy), which constitute twelve MEC value chains.

Like the previous three generations, the post-90s tourists realize the Vs of satisfaction and joy through the pursuit of the $\mathrm{A}$ of local delicacies and the $\mathrm{C}$ of culinary experience.

Similar to the post-60s and post-80s tourists, the post90 s tourists achieve the $\mathrm{V}$ of wisdom through the search for the As of ancient architecture and local traditional culture, as well as the Cs of spirit of workmanship and cultural experience and inheritance. These tourists are pragmatic, innovative, and aggressive $[97,98]$. They are curious about the unknown and good at learning [99]. The ancient architecture embodies exquisite craftsmanship, superb technology, and wisdom of the ancestors of the Chinese nation in the creative culture. All these factors inspire the post-90s tourists to have a deeper understanding of the wisdom in the spirit of workmanship among ancient architecture builders and the wisdom of the ancestors. Moreover, the post-90s tourists can acquire knowledge through travel and realize the $\mathrm{V}$ of selfimprovement (ancient architecture-spirit of workmanship-self-improvement; local traditional culture-cultural experience and inheritance-self-improvement).

For the post-90s tourists, the $\mathrm{V}$ of beautiful world originates from the As of environment of traditional village and natural landscape around traditional village and from 
TABLE 17: A-C connections of post-90s traditional village tourists (cutoff point $=50 \%$ ).

\begin{tabular}{|c|c|c|c|c|c|c|}
\hline A-C & A1 & A3 & A4 & A5 & A7 & A11 \\
\hline $\mathrm{C} 1$ & - & $96 / 121(85.7 \%)$ & - & - & - & - \\
\hline $\mathrm{C} 4$ & - & - & $60 / 100(60.0 \%)$ & - & - & - \\
\hline C5 & $48 / 82(58.5 \%)$ & - & - & - & - & - \\
\hline $\mathrm{C} 7$ & - & - & - & $65 / 101(64.4 \%)$ & - & - \\
\hline $\mathrm{C} 8$ & - & - & - & - & - & $61 / 90(61.8 \%)$ \\
\hline $\mathrm{C} 10$ & - & - & - & 一 & $46 / 79(58.2 \%)$ & $54 / 90(60.0 \%)$ \\
\hline
\end{tabular}

Percentage $=n / N$, where $N$ is the total number of respondents recognizing an $\mathrm{A}\left(\mathrm{A}_{i}\right)$ and $n$ is the number of respondents agreeing that $\mathrm{A}\left(\mathrm{A}_{i}\right)$ can produce a C $\left(\mathrm{C}_{i}\right)$.

TABLE 18: C-V connections of post-90s traditional village tourists (cutoff point $=50 \%$ ).

\begin{tabular}{|c|c|c|c|c|c|c|}
\hline $\mathrm{C}-\mathrm{V}$ & V1 & $\mathrm{V} 2$ & V3 & V5 & V7 & V10 \\
\hline$\overline{\mathrm{C} 1}$ & - & $88 / 101(87.1 \%)$ & - & - & - & $69 / 101(68.3 \%)$ \\
\hline $\mathrm{C} 4$ & - & - & - & - & $79 / 116(68.1 \%)$ & 39 \\
\hline $\mathrm{C} 5$ & - & - & $53 / 104(51.0 \%)$ & $75 / 90(72.1 \%)$ & - & - \\
\hline C7 & - & - & $95 / 132(72.0 \%)$ & $73 / 132(55.3 \%)$ & - & - \\
\hline $\mathrm{C} 8$ & - & - & - & - & $85 / 106(80.2 \%)$ & - \\
\hline $\mathrm{C} 10$ & $66 / 126(52.4 \%)$ & - & - & - & $82 / 126(65.1 \%)$ & - \\
\hline
\end{tabular}

Percentage $=n / N$, where $N$ is the total number of respondents recognizing a $\mathrm{C}\left(\mathrm{C}_{i}\right)$ and $n$ is the number of respondents agreeing that $\mathrm{C}\left(\mathrm{C}_{i}\right)$ can reflect a $\mathrm{V}\left(\mathrm{V}_{i}\right)$.

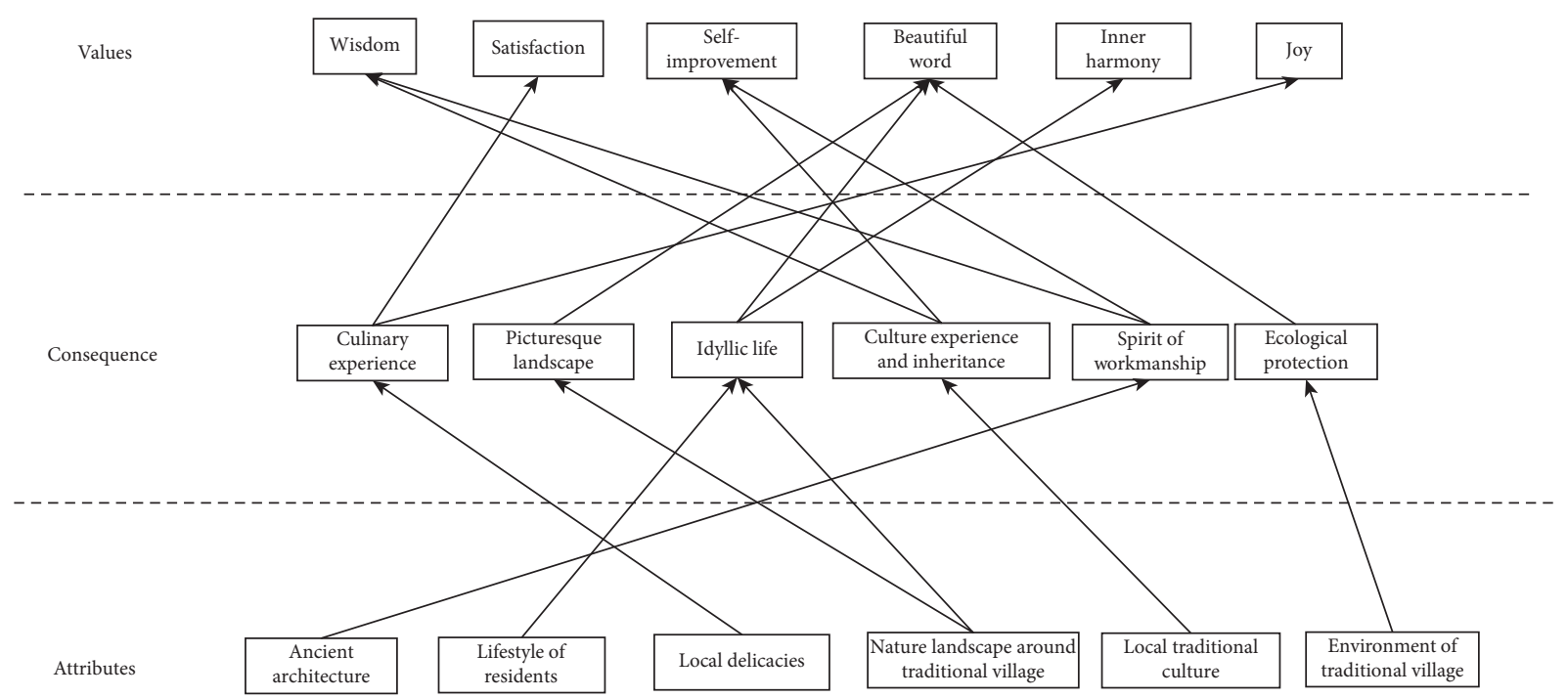

Figure 4: The HVM of post-90s tourists to traditional villages (including correlated factors only) (cutoff point $=50 \%$ ).

TABLE 19: The MEC value chains of traditional village tourists.

\begin{tabular}{|c|c|c|c|c|c|c|c|}
\hline & Attributes & Consequences & Values & $60 \mathrm{~s}$ & $70 \mathrm{~s}$ & $80 \mathrm{~s}$ & $90 \mathrm{~s}$ \\
\hline MEC1 & Ancient architecture & Wisdom of the ancients & Wisdom & $\checkmark$ & $\checkmark$ & - & - \\
\hline MEC2 & Ancient architecture & Spirit of workmanship & Wisdom & $\checkmark$ & - & $\checkmark$ & $\checkmark$ \\
\hline MEC3 & Local traditional culture & Cultural experience and inheritance & Wisdom & $\checkmark$ & - & $\checkmark$ & $\checkmark$ \\
\hline MEC4 & Environment of traditional village & Ecological protection & Beautiful world & - & $\checkmark$ & $\checkmark$ & $\sqrt{ }$ \\
\hline MEC5 & Environment of traditional village & Idyllic life & Beautiful world & - & $\checkmark$ & $\checkmark$ & - \\
\hline MEC6 & Natural landscape around traditional village & Picturesque landscape & Beautiful world & - & $\checkmark$ & $\checkmark$ & $\sqrt{ }$ \\
\hline MEC7 & Natural landscape around traditional village & Idyllic life & Beautiful world & - & $\checkmark$ & - & $\checkmark$ \\
\hline MEC8 & Water system of traditional village & Ecological protection & Beautiful world & - & - & $\checkmark$ & - \\
\hline MEC9 & Lifestyle of residents & Idyllic life & Beautiful world & - & - & - & $\checkmark$ \\
\hline MEC10 & Environment of traditional village & Idyllic life & Inner harmony & - & $\checkmark$ & $\checkmark$ & - \\
\hline MEC11 & Natural landscape around traditional village & Idyllic life & Inner harmony & - & $\checkmark$ & - & $\checkmark$ \\
\hline
\end{tabular}


TABle 19: Continued.

\begin{tabular}{|c|c|c|c|c|c|c|c|}
\hline & Attributes & Consequences & Values & $60 \mathrm{~s}$ & $70 \mathrm{~s}$ & $80 \mathrm{~s}$ & $90 \mathrm{~s}$ \\
\hline MEC12 & Natural landscape around traditional village & Picturesque landscape & Inner harmony & - & - & $\checkmark$ & - \\
\hline MEC13 & Lifestyle of residents & Idyllic life & Inner harmony & - & - & - & $\checkmark$ \\
\hline MEC14 & Ancient architecture & Spirit of workmanship & Self-improvement & $\checkmark$ & - & - & $\checkmark$ \\
\hline MEC15 & Local traditional culture & Cultural experience and inheritance & Self-improvement & $\checkmark$ & $\checkmark$ & $\checkmark$ & $\checkmark$ \\
\hline MEC16 & Local delicacies & Culinary experience & Satisfaction & $\checkmark$ & $\checkmark$ & $\checkmark$ & $\checkmark$ \\
\hline MEC17 & Local delicacies & Culinary experience & Joy & $\checkmark$ & $\checkmark$ & $\checkmark$ & $\checkmark$ \\
\hline MEC18 & Local traditional culture & Cultural experience and inheritance & Sense of belonging & - & $\checkmark$ & $\checkmark$ & - \\
\hline
\end{tabular}

the Cs of ecological protection and picturesque landscape. These As and Cs are commonly pursued by the previous three generations. Besides, this $\mathrm{V}$ also stems from the A of idyllic life yearned by the post-70s tourists. Out of curiosity, the post-90s tourists choose to experience the lifestyle of residents in traditional villages and find that the idyllic lifestyle of "getting up at sunrise and going to bed at sunset" is exactly what they have imagined about a beautiful world (lifestyle of residents-idyllic life-beautiful world).

In the meantime, as the previous two generations, the post-90s tourists are eager to temporarily escape the environment of daily life and work [99] and have a taste for the rural lifestyle [100]. The surrounding natural environment of traditional villages and the lifestyle of residents jointly create a slow and idyllic life, which eases the tourists' stress [94] and offers the $\mathrm{V}$ of inner harmony (lifestyle of residents-idyllic life-inner harmony; natural landscape around traditional village-idyllic life-inner harmony).

\section{Conclusions and Discussion}

5.1. Conclusions. According to the HVMs of traditional village tourists born in the 1960s, 1970s, 1980s, and 1990s, there are 36 MEC value chains of 18 classes for traditional village tourists (Table 19).

5.1.1. Intergenerational Preferences and Differences of Vs. The post-60s, post-70s, post-80s, and post-90s tourists pursue seven Vs, i.e., beautiful world, inner harmony, wisdom, selfimprovement, satisfaction, joy, and sense of belonging. The four generations of tourists share the following MEC value chains: local delicacies-culinary experience-satisfaction (MEC16); local delicacies-culinary experience-joy (MEC17); local traditional culture-cultural experience and inheritance-self-improvement (MEC15). Therefore, satisfaction, self-improvement, and joy are the Vs commonly pursued by the four generations. Furthermore, the self-improvement realized through local traditional culture is a pursuit of culture, while the satisfaction and joy brought by local delicacies are Vs on spiritual level. The research results show that tourism can bring happiness, satisfaction, and selfimprovement to tourists. This conclusion is applicable to the four generations from the post-60s to the post-90s, and there will be no difference in the values pursued by rural tourism due to generational differences.

The MEC value chains show that the post-60s tourists to traditional villages prefer the two Vs of wisdom and selfimprovement; the post-70s and post-80s prefer the three Vs of beautiful world, inner harmony, and sense of belonging. The post-90s tourists like all the Vs favored by the traditional village tourists of the previous three generations, a sign of the diversity and inclusiveness of the post-90s tourists [101].

5.1.2. Intergenerational Preferences and Differences of As. The post-60s, post-70s, post-80s, and post-90s tourists pursue seven As, i.e., ancient architecture, local delicacies, local traditional culture, environment of traditional village, natural landscape around traditional village, water system of traditional village, and lifestyle of residents. Specifically, ancient architecture refers to the ancient buildings and the homestays with local cultural features transformed from ancient architecture within the traditional villages; environment of traditional village refers to the atmosphere of human-nature harmony in traditional villages; natural landscape around traditional village refers to the natural landscape involving artificial or natural plants in the surroundings of traditional villages; lifestyle of residents refers to the slow and idyllic lifestyle of "getting up at sunrise and going to bed at sunset."

Ancient architecture, local delicacies, and local traditional culture are the common As of the four generations of tourists. The post-80s tourists prefer the A of water system of traditional village; the post-90s tourists prefer the A of lifestyle of residents, reflecting their curiosity; the post-70s, post-80s, and post-90s tourists prefer the As of environment of traditional village and natural landscape around traditional village.

5.1.3. Intergenerational Preferences and Differences of Cs. The post-60s, post-70s, post-80s, and post-90s tourists to traditional villages have seven Cs: idyllic life, cultural experience and inheritance, culinary experience, picturesque landscape, ecological protection, spirit of workmanship, and wisdom of the ancients.

Among the seven Cs, culinary experience, and cultural experience and inheritance are shared by all four generations. The post-70s, post-80s, and post-90s tourists prefer three Cs, namely, ecological protection, picturesque landscape, and idyllic life. This is because they wish to temporarily leave the stressful environment of daily life and work [99] and take a rest in the slow and idyllic life with superior ecological conditions. The post-60s and post-70s tourists prefer the $\mathrm{C}$ of wisdom of the ancients. Deeply affected by traditional Chinese culture, these two generations are attracted by the wisdom of our ancestors crystallized in the 
buildings, environment, and layout of traditional villages. The post-60s, post-80s, and post-90s prefer the spirit of workmanship among the builders of ancient architecture. Many ancient buildings in traditional villages are works of art, reflecting the Chinese culture and the craftsmanship of excellence. The research results show that tourists in these three ages will be motivated to explore the spirit of craftsmanship because of the ancient buildings in traditional villages.

According to the hierarchical value map (HVM) of tourists in traditional villages and the results of MEC chain research, we believe that the attributes of traditional villages produce the tourism consequence of traditional villages, and the tourism value of traditional villages is realized through the experience of the tourism consequence of villages. Meanwhile, the ultimate tourism value reflects the spiritual needs of tourists. It also affects the protection of traditional village attributes and their reuse in sustainable tourism development, so that attributes $\longrightarrow$ consequence $\longrightarrow$ value $\longrightarrow$ attributes form a cycle of mutual influence and interaction of the transmission of village protection and activation model. In this process, the attribute of traditional villages is the basis of tourism activation, and the tourism consequence of traditional villages is the guidance of tourism activation. The tourism value of traditional villages, which reflects tourists' tourism values and value pursuit, is the core of tourism activation. It is also an important factor affecting the sustainable development of traditional village tourism.

5.2. Discussion. This paper collects 600 samples of traditional village tourists across China and explores the tourism values behind the tourist behaviors through hard laddering. The main findings are as follows:

(1) From value preferences, it can be learned that the post-60s traditional village tourists are a generation of wisdom-loving learners, the post-70s and 80s tourists are a generation of beauty lovers with a strong sense of belonging, and the post-90s tourists are a generation of inclusive advocators of diversity.

(2) From the root and source, this paper summarizes the essence of the sustainable development of traditional villages: realizing the ultimate values of tourists, such as joy, wisdom, satisfaction, sense of belonging, selfimprovement, inner harmony, and beautiful world, through careful protection of the following attributes of traditional villages: local delicacies, local traditional culture, ancient architecture, lifestyle of residents, environment of traditional village, and natural landscape around traditional village.

(3) The MEC theory proved to be effective for the study of different types of tourists to traditional villages, the discovery of the value preferences and intergenerational differences of such tourists, and the accurate prediction of their intergenerational preferences, providing theoretical support and practical enlightenment to the product development and marketing of the niche markets of traditional village tourism.
(4) The research results help to activate the traditional village tourism, adapt to the latest changes in the tourism market, and inherit and innovate the traditional culture of traditional villages. After experiencing the traditional culture, the tourists are very likely to spread the culture voluntarily. Besides, the tourists can affect the culture of traditional villages during travel. Through these pathways, it is possible to inherit and renovate the traditional culture in traditional villages, enhance the confidence in traditional culture, and promote rural revitalization.

The contribution of this research lies in the in-depth study of the value preferences and intergenerational differences of traditional village tourists born in the 1960s, 1970s, 1980s, and 1990s and the subdivision of traditional village tourism market into different generations, providing theoretical support to and bridge the research gap of the product development for the niche markets of traditional village tourism.

Due to space limitations, this paper only analyzes the MEC value chains above the cut-off point (50\%). The MEC value chains below that point were not considered. Besides, the authors did not deeply explore the relationship between the tourist values and the protection and activation of traditional villages. Adding the intergenerational values of traditional village tourists, the future work will try to establish a model for the protection and activation of traditional villages and to safeguard the key attributes or activities of traditional villages.

Finally, several suggestions were presented for the activation of traditional village tourism:

(1) To revive the attributes and values of traditional villages, it is necessary to marketize the tourist values of traditional villages like satisfaction, self-improvement, wisdom, and joy, which are the results of ancient architecture, local delicacies, environment of traditional village, and local traditional culture.

(2) The following attributes of traditional villages should be protected with special care: local delicacies, local traditional culture, ancient architecture, lifestyle of residents, environment of traditional village, and natural landscape around traditional village.

(3) Considering the MEC value chains of post-60s, post70 s, post- 80 s, and post- 90 s tourists, it is important to design tourism products meeting the market needs of different generations, making the tourism products of traditional villages livelier.

(4) It is necessary to establish a government-led, villager-dominated, and market-driven mechanism to activate the traditional villages. Under the mechanism, it would be possible to develop new tourism businesses and products for traditional villages, carry out marketization targeted at specific groups of tourists, and improve the service level, laying the basis for rural revitalization and sustainable development of traditional villages. 


\section{Data Availability}

The data used to support the findings of this study are available from the corresponding author upon request.

\section{Conflicts of Interest}

The authors declare that they have no conflicts of interest.

\section{References}

[1] Y. Ming and W. Q. Cao, "Reconstruction of the textual consciousness of the protection and development of traditional village culture," Guizhou Social Sciences, vol. 11, pp. 76-83, 2016.

[2] H. Y. Song, "Study on the risk and prevention of tourismification protection of traditional villages," Journal of Original Ecological National Culture, vol. 9, no. 2, pp. 95-98, 2017.

[3] B. H. Wu, "Protection and activation of traditional villages based on rural tourism," Social Scientist, vol. 226, no. 2, pp. 7-9, 2016.

[4] J. Y. Chung, C.-C. Chen, and Y.-H. Lin, "Cross-strait tourism and generational cohorts," Journal of Travel Research, vol. 55, no. 6, pp. 813-826, 2016.

[5] M. Cleaver, B. C. Green, and T. E. Muller, "Using consumer behavior research to understand the baby boomer tourist," Journal of Hospitality \& Tourism Research, vol. 24, no. 2, pp. 274-287, 2000.

[6] Y. P. Yu, Y. Y. Wu, and W. Wang, "Analysis of tourism consumption preference based on intergenerational differences," Commercial Times, vol. 16, pp. 43-45, 2017.

[7] T. Wagner, "Shopping motivation revised: a means-end chain analytical perspective," International Journal of Retail \& Distribution Management, vol. 35, no. 7, pp. 569-582, 2007.

[8] C. Y. Wang and F. C. Huang, "An empirical study on the definition and classification of stakeholders in village heritage sites: a case study of Kaiping watchtower and village," Tourism Tribune, vol. 27, no. 8, pp. 88-94, 2012.

[9] F. Li and Z. Y. Cai, "Study on stakeholders in tourism development of ancient villages: a case study of Daqitou ancient village," Tourism Tribune, vol. 22, no. 1, pp. 42-48, 2007.

[10] Z. Y. Che, "The spatial form evolution from traditional villages to small towns in tourism development," Tourism Tribune, vol. 32, no. 1, pp. 10-11, 2017.

[11] F. Li and Z. M. Jin, "The comparative study of the tourist impact on ancient villages in southern Anhui: a case study of Xidi, Hongcun and Nanping villages," Human Geography, vol. 17, pp. 17-20+96, 2002.

[12] W. H. Li, Z. B. Zhao, and Y. H. Li, "An analysis of comprehensive perception and variations of residents in ancient village tourism areas: a case study of Dangjiacun in Hancheng, Shaanxi," Tourism Science, vol. 20, no. 6, pp. 52-58, 2006.

[13] C. X. Liu, "Study on farmers' cognition and attitude towards rural tourism development: a case study of Xidi and Hongcun villages in southern Anhui," Commercial Research, vol. 9, pp. 164-169, 2008.

[14] S. Lu and J. Zhang, "Study on life satisfaction and community construction of ancient village tourism communities: a case study of ancient villages in southern Anhui, a world cultural heritage," Tourism Science, vol. 3, pp. 41-47, 2009.
[15] M. Ghanian, O. M. Ghoochani, and J. C. Crotts, “An application of European performance satisfaction index towards rural tourism: the case of western Iran," Tourism Management Perspectives, vol. 11, no. 1-2, pp. 77-82, 2014.

[16] H. Chen, P. Li, and C. Y. Wang, "Analysis of spatial differences in tourism perception and attitude of residents in village-type heritage sites," Journal of South China Normal University (Natural Science Edition), vol. 49, no. 4, pp. 88-94, 2017.

[17] W. Q. Tang and Y. S. Wang, "Research on the utilization of cultural resources in the construction of ethnic tourist villages: a case study of Shemihu village, Enshi prefecture," Journal of Hubei Institute for Nationalities (Philosophy and Social Sciences), vol. 34, no. 3, pp. 34-36, 2016.

[18] S. Falak, L. M. Chiun, and A. Y. Wee, "A repositioning strategy for rural tourism in Malaysia-community's perspective," Procedia-Social and Behavioral Sciences, vol. 144, pp. 412-415, 2014.

[19] A. F. Amir, A. A. Ghapar, S. A. Jamal, and K. N. Ahmad, "Sustainable tourism development: a study on community resilience for rural tourism in Malaysia," Procedia-Social and Behavioral Sciences, vol. 168, no. 9, pp. 116-122, 2015.

[20] A. R. A. Razzaq, N. H. Mohamad, S. S. S. A. Kader et al., "Developing human capital for rural community tourism: using experiential learning approach," Procedia-Social and Behavioral Sciences, vol. 93, pp. 1835-1839, 2013.

[21] V. R. Vitasurya, "Local wisdom for sustainable development of rural tourism, case on Kalibiru and Lopati village, province of Daerah Istimewa Yogyakarta," Procedia-Social and Behavioral Sciences, vol. 216, pp. 97-108, 2016.

[22] X. Y. Yu, "Study on community tourism model in China: a case study of Huizhou ancient villages," Human Geography, vol. 21, no. 5, pp. 41-45, 2006.

[23] X. Y. Shen and H. B. Bu, “"Symbiosis anagenesis” research about ancient village tour corporation in China: an analysis based on symbiosis theory," Economic Geography, vol. 26, no. 2, pp. 322-325, 2006.

[24] S. H. Feng, "Discussion on symbiosis evolution model of ancient villages based on symbiosis theory," Economic Geography, vol. 33, no. 11, pp. 155-162, 2013.

[25] H. P. Jiang, Y. H. Wang, and J. L. Li, "Research on development models of ancient villages based on community management: a case study of world cultural heritage-Xidi village and Hongcun village," East China Economic Management, vol. 23, no. 8, pp. 24-28, 2009.

[26] P. L. Liu and C. L. Liu, "Typical model of valley economy in Beijing mountainous area and its enlightenment to the protection of ancient villages in mountainous areas," Economic Geography, vol. 30, no. 12, pp. 1944-1949, 2010.

[27] F. Q. Wei, "Mixed-effect model of traditional ancient village protection and tourism development," Journal of Arid Land Resources and Environment, vol. 24, no. 10, pp. 197-200, 2010.

[28] L. P. Li, "Research on tourism development model of ancient villages based on multi-dimensional attribute integration: a case study of historic and cultural famous villages," Human Geography, vol. 4, pp. 155-160, 2013.

[29] J. G. Zhu, "Production in tourist attractions and reconstruction of ethnic culture: a study on tourism anthropology in a Buyi village," Journal of Guangxi University for $\mathrm{Na}$ tionalities (Philosophy and Social Sciences Edition), vol. 6, pp. 76-81, 2010.

[30] R. Yu, L. Liang, and D. Li Deming, "Research on the invasion and succession of tourism population and the spatial order 
reorganization of ancient villages: a case study of Hongcun village in Huizhou," Economic Geography, vol. 33, no. 8, pp. 165-170, 2013.

[31] S. Lu, Y. C. Zhang, and L. L. Wang, "Social integration structure and determinant of tourism migration in ancient village: a case study of Hongcun village," Human Geography, vol. 32, no. 4, pp. 138-145, 2017.

[32] R. Liu, "On contemporary rural cultural change and acculturation," Scientific and Technological Innovation, vol. 31, p. 92, 2009.

[33] W. B. Li, "Latest research on domestic ancient village tourism," Journal of Jiangsu Ocean University (Humanities \& Social Edition), vol. 3, pp. 69-72, 2008.

[34] C. Y. He, "Protection and development of ancient villages in Nanxijiang scenic spot," Journal of Beijing Institute of Civil Engineering and Architecture, vol. 2, pp. 26-32, 1989.

[35] K. Ouyang and Z. T. Yang, "On cultural tourism resources of ancient rural settlements in China," Human Geography, vol. 3, pp. 48-53, 1993.

[36] F. C. Liu, "Research on the change and influence of ancient village soundscape based on residents' perception: a case study of Hongcun village, Anhui Province," Tourism Science, vol. 31, no. 4, pp. 49-63, 2017.

[37] S. H. Feng, "Analysis of tourist source market and research on behavioral pattern in ancient villages," Tourism Tribune, vol. 7, no. 6, pp. 45-48, 2002.

[38] N. Yuan, "Tourism resource evaluation of ancient villages based on analytic hierarchy process: a case study of world heritage sites Xidi and Hongcun villages," Resources Development \& Market, vol. 28, no. 2, pp. 179-181, 2012.

[39] R. Zhou, L. S. Zhong, and J. M. Liu, "Connotation and tourism utilization of rural world heritage sites," Geographical Research, vol. 34, no. 5, pp. 991-1000, 2015.

[40] G. D. Hao, "Review of the status quo of ancient villages on promoting sports leisure tourism: a case study of dwellings in Zhenshan village, Guizhou province," Guizhou Ethnic Studies, vol. 37, no. 2, pp. 134-137, 2016.

[41] Q. Cheng and J. Fu, "Research on evaluation of ancient village tourism resources based on visitor perception," Economic Geography, vol. 30, no. 2, pp. 329-333, 2010.

[42] W. Xu and Y. Li, "Index construction and evaluation of tourism authenticity perception of ancient villages: based on empirical data of ancient villages in southern Anhui," $\mathrm{Hu}$ man Geography, vol. 3, pp. 98-102, 2012.

[43] Q. Su, Y. Cao, and H. Zhang, "Study on tourists' motivation and behavior types: a case study of Xidi village, a world heritage site," Human Geography, vol. 20, no. 4, pp. 82-86, 2005.

[44] C. X. Liu, "Research on tourism thrust-pull factors of world heritage sites: a case study of Xidi and Hongcun villages," Tourism Tribune, vol. 20, no. 5, pp. 15-20, 2005.

[45] W. Rid, I. O. Ezeuduji, and U. Pröbstl-Haider, "Segmentation by motivation for rural tourism activities in the Gambia," Tourism Management, vol. 40, no. 2, pp. 102-116, 2014.

[46] F. D. Matei, "Cultural tourism potential, as part of rural tourism development in the north-east of Romania," Procedia Economics and Finance, vol. 23, pp. 453-460, 2015.

[47] S. Lu, L. Lu, and M. Xu, "Research on the overseas tourist market of the ancient villages in Yixian county, Anhui province," Economic Geography, vol. 25, no. 2, pp. 252-256, 2005.

[48] H. Q. Lu, Q. Su, and A. Zhao, "A study on consuming behavior and optimization of tourism supply system of female tourists: a case study of Hongcun village," Journal of Anhui Normal University (Natural Science), vol. 40, no. 3, pp. 282-286, 2017.

[49] S. Lu and X. Wu, "Evaluation of the satisfaction degree of sketching tourists in ancient villages: a case study of Hongcun village, Yixian county," Geographical Research, vol. 36, no. 8, pp. 1570-1582, 2017.

[50] V. F. Guzman-Parra, C. Quintana-García, C. A. BenavidesVelasco, and J. R. Vila-Oblitas, "Trends and seasonal variation of tourist demand in Spain: the role of rural tourism," Tourism Management Perspectives, vol. 16, pp. 123-128, 2015.

[51] K. Mannheim, "The problem of a sociology of knowledge," Essays on the Sociology of Knowledge, pp. 134-190, Routledge, London, UK, 1952.

[52] N. B. Ryder, "The Cohort as a concept in the study of social change," Cohort Analysis in Social Research, Springer, New York, NY, USA, pp. 9-44, 1985.

[53] R. Inglehart, Modernization and Postmodernization: Cultural, Economic, and Political Change in 43 Societies, Cambridge University Press, Cambridge, UK, 1997.

[54] H. Schuman and J. Scott, "Generations and collective memories," American Sociological Review, vol. 54, no. 3, pp. 359-381, 1989.

[55] R. Eyerman and B. S. Turner, "Outline of a theory of generations," European Journal of Social Theory, vol. 1, no. 1, pp. 91-106, 1988.

[56] S. Gardiner, C. King, and D. Grace, "Travel decision making," Journal of Travel Research, vol. 52, no. 3, pp. 310-324, 2013.

[57] S. Beldona, "Cohort analysis of online travel information search behavior: 1995-2000," Journal of Travel Research, vol. 44, no. 2, pp. 135-142, 2005.

[58] H. L. Furr, M. A. Bonn, and A. Hausman, "A generational and geographical analysis of internet travel-service usage," Tourism Analysis, vol. 6, no. 2, pp. 139-147, 2001.

[59] Y. C. Huang and J. F. Petrick, "Generation Y's travel behaviours: a comparison with baby boomers and generation X," Tourism and Generation Y, pp. 27-37, CABI Publishing, Cambridge, UK, 2010.

[60] L. Pennington-Gray, D. L. Kerstetter, and R. Warnick, "Forecasting travel patterns using Palmore's cohort analysis," Journal of Travel \& Tourism Marketing, vol. 13, no. 1/2, pp. 125-143, 2002.

[61] X. Y. Lehto, S. Jang, F. T. Achana, and J. T. O'Leary, "Exploring tourism experience sought: a cohort comparison of baby boomers and the silent generation," Journal of Vacation Marketing, vol. 14, no. 3, pp. 237-252, 2008.

[62] M. Kruger and M. Saayman, "Consumer preferences of generation $\mathrm{Y}$ : evidence from live music tourism event performances in South Africa," Journal of Vacation Marketing, vol. 21, no. 4, pp. 366-382, 2015.

[63] Q. F. Huang, Y. Q. Lu, and X. Y. Chen, "A review of intergenerational theory and its application in tourism research," Tropical Geography, vol. 38, no. 1, pp. 25-33, 2008.

[64] L. M. Cui, C. M. Cao, and Y. M. Liang, "Intergenerational theory and a comparative study on the tourism behaviors of the "post-80s" and "post-90s"," China Economist, vol. 2, pp. 200-201, 2012.

[65] F. Q. Wang and C. Chang, "Comparative analysis of tourism consumption behaviors of "post-80s" and "post-90s"," Modern Business Trade Industry, vol. 36, no. 8, pp. 62-64, 2015.

[66] G. J. Zhang, J. F. Wu, and J. C. Zhou, "Comparison of intergenerational differences of tourist destination 
images-also on three different theories of generation gap theory," Tourism Tribune, vol. 32, no. 2, pp. 53-64, 2017.

[67] Y. B. Yang, "Comparative studies on intergenerational difference of tourism consumer behavior," M.Sc. Thesis, East China Normal University, Shanghai, China, 2014.

[68] L. M. Liu and X. Y. Liu, "Research on the change of social concept based on the intergenerational difference of female tourism consumption behavior," Market Modernization, vol. 15, pp. 270-272, 2015.

[69] X. Y. Yao and Y. L. Luo, "Research on the intergenerational difference of domestic tourists' consumption behavior in mountain tourism destinations: a case study of Zhangjiajie," Resources Development \& Market, vol. 29, no. 10, pp. 1094-1097, 2013.

[70] Y. R. Jia, Q. Zhou, and J. Huang, "Comparison of intergenerational differences in tourism information searching behavior," Tourism Overview, vol. 11, p. 11+13, 2018.

[71] W. Qi, "Pursuit of traditional village value from the perspective of tourists," Doctoral Thesis, Hong Kong Polytechnic University, Hong Kong, China, 2019.

[72] T. Reynolds and J. Olson, Understanding Consumer Decision Making: The Means-End Approach to Marketing and Advertising Strategy, Lawrence Erlbaum Associates, New Jersey, NY, USA, 2010.

[73] J. Gong, "Research on the development mode of international tourism island," Doctoral Thesis, Wuhan University, Wuhan, China, 2010.

[74] B. Kim, S. S. Kim, and B. King, "The sacred and the profane: identifying pilgrim traveler value orientations using meansend theory," Tourism Management, vol. 56, pp. 142-155, 2016.

[75] B. Richter and W. Bokelmann, "The significance of avoiding household food waste-a means-end-chain approach," Waste Management, vol. 74, pp. 34-42, 2018.

[76] S. Jiang, N. Scott, and P. Ding, "Motivations of experienced leisure travellers: a means-end chain study on the Chinese outbound market," Journal of Vacation Marketing, vol. 25, no. 2, pp. 225-238, 2019.

[77] J. J. Guan, "Review of gourmet abroad and tourism studies: talking about the extensive phenomenon of the concept of gourmet travel," Tourism Tribune, vol. 27, no. 10, pp. 85-92, 2012.

[78] S. N. Isye and H. Raidah, "Mapping of culinary tourism distribution based on web data mining information. case study, Bandar Lampung city," IOP Conference Series, Earth and Environmental Science, vol. 258, no. 1, p. 012040, 2019.

[79] J. Kivela and J. C. Crotts, "Tourism and gastronomy: gastronomy's influence on how tourists experience a destination," Journal of Hospitality \& Tourism Research, vol. 30, no. 3, pp. 354-377, 2006.

[80] H. Xu, "Rational reflection on the transformation of consumption ethics," Journal of Shanxi Provincial Committee Party School of C.P.C.vol. 4, pp. 64-66, 2013.

[81] Canadian Tourism Commission, "Travel activities and motivation survey: interest in agrotourism," 2000, http:// www1.agric.gov.ab.ca/\$department/deptdocs.nsf/all/apa547/ \$FILE/ctcagri_tourism_study.pdf.

[82] P. L. Pearce, "Farm tourism in New Zealand: a social situation analysis," Annals of Tourism Research, vol. 17, no. 3, pp. 335-352, 1990.

[83] A. Murphy and P. W. Williams, "Attracting Japanese tourists into the rural hinterland: implications for rural development and planning," Tourism Management, vol. 20, no. 4, pp. 487-499, 1999.
[84] J. M. Frater, "Farm tourism in England-planning, funding, promotion and some lessons from Europe," Tourism Management, vol. 4, no. 3, pp. 167-179, 1983.

[85] S. X. Liu and Z. M. Zhou, "Cultural values of contemporary Chinese consumers and its marketing implications," Corporate Finance, vol. 6, pp. 10-13, 2002.

[86] J. E. Coryell, "The foreign city as classroom: adult learning in study abroad," Adult Learning, vol. 22, no. 3, pp. 4-11, 2011.

[87] C. Ryan, "Equity, management, power sharing and sustainability-issues of the "new tourism"," Tourism Management, vol. 23, no. 1, pp. 17-26, 2002.

[88] Y. X. Long, "Preliminary study on rural tourism development strategy based on cultural marketing," Rural Economy, vol. 6, pp. 59-61, 2009.

[89] X. Fu, L. Cai, and X. Lehto, "A confucian analysis of Chinese tourists' motivations," Journal of Travel \& Tourism Marketing, vol. 32, no. 3, pp. 180-198, 2015.

[90] T. Zhang and W. Y. Chen, "Zhouyi and the YinYang school of the pre-qin period," Theory Journal, vol. 11, pp. 105-114, 2015.

[91] J. M. He and L. H. Li, "Index," Diabetes Research, Second Edition, vol. 28, no. 5, pp. 125-128, 2002.

[92] B. N. Han and J. W. Wang, "On the rural tourism development model of the three northeastern provinces-based on "City-Village" growth poles model," Journal Beijing International Studies University, vol. 3, pp. 50-55, 2009.

[93] M. M. Li, Z. W. Huang, and L. A. Cai, "Benefit segmentation of visitors to a rural community-based festival," Journal of Travel \&Tourism Marketing, vol. 26, no. 5-6, pp. 585-598, 2009.

[94] R. Zeng, "Investigation and research on the rural tourism behavior of Chengdu citizens-also on the development direction of rural tourism with Chengdu characteristics," The Science Education Article Collects, vol. 31, p. 179, 2007.

[95] M. Z. Zhang, S. Lu, and B. Z. Guan, "On the behavioral characteristics and perceptions towards rural tourism of Shanghai residents," Journal of Subtropical Resources and Environment, vol. 3, pp. 82-87, 2007.

[96] X. L. Chai, "Analysis of intergenerational differences of tourists' travel behavior," Doctoral Thesis, Shaanxi Normal University, Shaanxi, China, 2016.

[97] X. Q. Deng, "Research on the new values of "post-90s"," Ideological \& Theoretical Education, vol. 9, pp. 23-30:53, 2016.

[98] L. L. Wei, "The identification of the core socialist values among the "post-80s" and "post-90s" youth-based on the comparison between generations and classes," Contemporary Youth Research, vol. 2, pp. 17-23, 2017.

[99] Z. Zhang, "Research on consumer culture changes in China since the reform and opening up," Doctoral Thesis, Beijing Jiaotong University, Beijing, China, 2013.

[100] J. Swarbrooke, Culture, Tourism, and Sustainability of Rural Areas in Europe, p. 453, University of Northumbria, Newcastle, UK, 1996.

[101] J. H. Bu, L. W. Meng, and Z. W. Zhang, "Diagnosis and support of social mentality of group images of "Buddha-like youth", China Youth Study, vol. 273, no. 11, pp. $62+106-112,2018$. 